\title{
Hairless canary seeds (Phalaris canariensis L.) as a potential source of antioxidant, antihypertensive, antidiabetic, and antiobesity biopeptides
}

\author{
U. C. Urbizo-Reyes, J. E. Aguilar-Toalá and A. M. Liceaga*
}

\begin{abstract}
Rising consumer concerns with synthetic drugs to treat non-communicable diseases (NCDs) have promoted a shift towards using natural biological active constituents that offer similar health benefits. Hairless canary seed (Phalaris canariensis $L$ ) is an emerging crop traditionally used in Mexico to treat NCDs. Peptides liberated during simulated digestion of canary seed protein are believed to be responsible for their biological activity; however, no studies have shown the effect of controlled protein hydrolysis using commercial proteases on canary seed protein's biological activity. Therefore, this study aimed to explore the in vitro antihypertensive, antidiabetic, and anti-obesity activity of canary seed peptides derived from proteolysis with Alcalase ${ }^{\oplus}$. Protein fractions were primarily composed of prolamins ( $54.07 \pm 1.8 \%)$, glutelins $(32.19 \pm 3.18 \%)$, globulins $(5.97 \pm 0.52 \%)$ and albumins $(5.97 \pm 0.52 \%)$. The $<3$ kDa and 3-10 kDa peptide fractions showed the highest inhibition capacity $(p<0.05)$ towards angiotensinconverting enzyme $\left(I C_{50}=0.028-0.032 \mathrm{mg} / \mathrm{mL}\right)$ lipase $\left(I C_{50}=2.15-2.27 \mathrm{mg} / \mathrm{mL}\right)$, a-glucosidase $\left(I C_{50}=0.82-1.15 \mathrm{mg} /\right.$ $\mathrm{mL})$, and dipeptidyl-peptidase-IV $\left(\mathrm{IC}_{50}=1.27-1.60 \mathrm{mg} / \mathrm{mL}\right)$. Additionally, these peptide fractions showed high

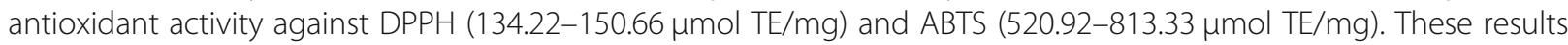
provide an insight into the potential development of functional foods using commercial enzymatic hydrolysis of canary seed proteins for treating hypertension, type-2 diabetes, and obesity.
\end{abstract}

Keywords: Canary seeds, Bioactive peptides, Anti-obesity activity, Antihypertensive activity, Antidiabetic activity

\section{Introduction}

Globally, chronic diseases have become a major challenge to public health. It is estimated that 7 out of the 10 leading causes of death in the United States are attributed to these diseases, with approximately $50 \%$ of Americans living with at least one chronic illness (CDC, 2020). Unhealthy diet habits, genetic traits, and environmental influences have increased the development of chronic diseases such as obesity, hypertension, and type2 diabetes (Cicero et al. 2017; Chatterjee et al. 2018).

\footnotetext{
* Correspondence: aliceaga@purdue.edu

Protein Chemistry and Bioactive Peptides Laboratory, Department of Food Science, Purdue University, 745 Agriculture Mall Drive, West Lafayette, IN 47907, USA
}

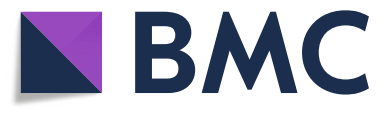

(c) The Author(s). 2021 Open Access This article is licensed under a Creative Commons Attribution 4.0 International License, which permits use, sharing, adaptation, distribution and reproduction in any medium or format, as long as you give

appropriate credit to the original author(s) and the source, provide a link to the Creative Commons licence, and indicate if changes were made. The images or other third party material in this article are included in the article's Creative Commons licence, unless indicated otherwise in a credit line to the material. If material is not included in the article's Creative Commons licence and your intended use is not permitted by statutory regulation or exceeds the permitted use, you will need to obtain permission directly from the copyright holder. To view a copy of this licence, visit http://creativecommons.org/licenses/by/4.0/. known to cause temporary or permanent side effects (e.g., fever, chills, cough, sore throat, convulsions or seizures) (Kumar et al. 2010). For example, some antihypertensive drugs such as Captopril and Enalapril can cause cough and skin rashes, or the anti-obesity drug Orlistat can cause diarrhea and dyspepsia. The rising consumer awareness and health concerns towards utilizing synthetic drugs to treat chronic conditions have driven research to focus on natural or food derived constituents that offer similar health benefits and have less adverse side effects (Chen et al. 2009; Ishida et al. 2011). These natural compounds include phytochemicals, fatty acids, carbohydrates, and bioactive peptides, among 
others (Coelho et al. 2019). Bioactive peptides are organic molecules produced by proteolysis and formed by amino acids joined by covalent bonds, these molecules are known to have positive effects on metabolic functions of living organisms and consequently in human health (Sánchez and Vázquez 2017). In this context, bioactive peptides can provide functional properties to foods by inhibiting enzymes such as dipeptidyl peptidase-IV (DPP-IV), angiotensin-converting enzyme (ACE), and lipase, resulting in therapeutic benefits that serve as anti-hypertensive, anti-diabetic, and anti-obesity agents (Konrad et al. 2014).

Hairless canary seed (Phalaris canariensis L) is considered an emerging crop. In the past few decades, these seeds had been principally designated as birdfeed due to the presence of small carcinogenic siliceous hairs attached to the hull of the seed, which prevented them from being utilized for human consumption; nonetheless, novel varieties lacking these hairs showed to be safe for human consumption (Abdel-Aal et al. 1997). Hairless varieties of canary seeds (CDC Cibo, CDC Calvi, CDC Maria, CDC Togo, and CDC Bastia) were recently highlighted as GRAS by the Food and Drug Administration (FDA). Due to their rich protein composition (19$24 \%$ ), canary seeds have potential to be used as a functional and nutritional ingredient for human consumption (Mason 2019). Hairless canary seeds have served as a traditional remedy in Mexico for hundreds of years to treat obesity, diabetes, and hypertension (Estrada-Salas et al. 2014). The seeds are consumed as a milky solution, often referred to as canary seed milk (Perez Gutierrez et al. 2016). Mason et al. (2018), give a detailed overview of the health benefits of hairless canary seed milk associated with the presence of small peptides produced during the process of gastrointestinal digestion of the proteins. However, a research gap remains regarding the current knowledge of the effect of a controlled, commercial proteolysis on canary seed peptides' inhibitory activity towards specific enzymes (angiotensin-converting, dipeptidyl peptidase-IV, lipase, and $\alpha$ glucosidase enzymes) that are related to chronic conditions. Thus, the objective of this study was to examine the effect of commercial enzymatic hydrolysis with Alcalase $^{\bullet}$ of defatted canary seed flour on biological activities of canary seed peptides.

\section{Materials and methods Materials}

Hairless canary seeds of the CDC Cibo variety were purchased from a commercial vendor (Canpulse Foods LTD, Saskatoon, SK, Canada). Alcalase ${ }^{\circ}$ (protease from Bacillus licheniformis, EC 3.4.21.62) and Lecitase ${ }^{\circ}$ Ultra (Phospholipase A1 from Aspergillus oryzae) were purchased from Sigma Aldrich (St. Luis, MO, USA). Human
Angiotensin-Converting Enzyme (ACE), Dipeptidyl Peptidase IV (DPP-IV, $\geq 4500$ units/ $\mu$ g protein), and their substrates Gly-Pro p-nitroanilide hydrochloride, and Hippuryl-L-Histidyl-L-Leucine (HHL), respectively, were all purchased from Sigma Aldrich (St. Louis, MO, USA). All chemicals used in this study were reagentgrade obtained by three leading companies VWR International (Radnor, PA, USA), Sigma Aldrich (St. Louis, MO, USA), and Thermo Fisher Scientific (Waltham, MA, USA).

\section{Proximate composition}

Canary seeds were analyzed for moisture, ash, lipid, and protein content following the AOAC methods 950.46(b), 920.153, 960.39, and 984.13 (A-D), respectively (AOAC 2016) through a commercial analytical laboratory (A\&L Great Lakes, Fort Wayne, IN, USA).

\section{Defatting of canary seeds}

Canary seeds were defatted using the method described in Urbizo-Reyes et al. 2019 using a mechanical oil press (Beamnova Automatic Commercial 304 Stainless Steel Expeller, Guangzhou, China). The defatted material was ground into a fine powder and referred to as canary seed powder.

\section{Isolation of storage protein fractions}

The storage protein fractions of canary seeds were isolated according to the Osborne classification following the methodology proposed by Estrada-Salas et al. (2014) with slight modifications. Briefly, canary seed powder was solubilized in deionized water $(1: 10, \mathrm{w} / \mathrm{v})$, stirred for $1 \mathrm{~h}$ at $4{ }^{\circ} \mathrm{C}$ and then centrifuged $10,000 \times \mathrm{g}$ for $20 \mathrm{~min}$ at $4{ }^{\circ} \mathrm{C}$. The supernatant was collected as a source of albumin fractions. The pellet was resuspended $(1: 10, \mathrm{w} / \mathrm{v})$ in potassium phosphate monobasic $(0.01 \mathrm{M})$, sodium chloride $(0.1 \mathrm{M})$, and EDTA $(1 \mathrm{mM})(\mathrm{pH} 7.5)$ followed by the same centrifugation process described above, then the supernatant was recovered as a source of globulin $7 \mathrm{~s}$ fractions. A similar extraction was carried out using a potassium phosphate monobasic $(0.01 \mathrm{M})$, sodium chloride $(0.8 \mathrm{M})$, and EDTA $(1 \mathrm{mM})(\mathrm{pH} 7.5)$, and the supernatant was referred to as globulin $11 \mathrm{~s}$. Next, the pellet was resuspended in isopropanol $70 \%(1: 10, \mathrm{w} / \mathrm{v})$ and centrifuged as described above; the recovered supernatant was the source of prolamin proteins. Finally, the resulting pellet was solubilized in a sodium hydroxide $(0.1 \mathrm{M})$ solution, centrifuged, and the supernatant collected was considered the source of glutelins. The extraction yield of each storage protein fraction was measured using the bicinchoninic acid (BCA) protein assay (Thermo Scientific, Rockford, IL, USA) and reported as a percentage (protein content of storage fraction/total protein in canary seed). 


\section{Sodium dodecyl sulfate polyacrylamide gel electrophoresis (SDS-PAGE)}

Storage protein fractions were dissolved to $2 \mathrm{mg} / \mathrm{mL}$ in zwitterionic-chaotropic buffer (2D-gel extraction buffer; $50 \mathrm{mM}$ Tris- $\mathrm{HCl}, \mathrm{pH} 8.8,10 \mathrm{mM}$ ethylenediaminetetraacetic acid (EDTA), $5 \mathrm{M}$ urea, $2 \mathrm{M}$ thiourea, $2 \%$ (w/v) 3 3-[(3-Cholamidopropyl)dimethylammonio]1-propanesulfonate (CHAPS), $67 \mathrm{mM}$ Dithiothreitol (DTT) and stirred for $1 \mathrm{~h}$ at room temperature. Protein fractions $(50 \mu \mathrm{L})$ were added to $50 \mu \mathrm{L}$ Laemmeli Sample Buffer having a final concentration $1 \mathrm{mg} / \mathrm{mL}$. The protein fractions were loaded using $20 \mu \mathrm{L}$ onto 4-12\% gradient gels (Bis-Tris, NuPAGE, ThermoScientific, Waltham, MA) and ran with MES SDS running buffer (NuPAGE, ThermoScientific, Waltham, $\mathrm{MA})$ at $200 \mathrm{~V}$ for $45 \mathrm{~min}$. The gel was stained overnight using Coomassie R-250 and destained overnight. The molecular weight distribution was determined using Precision Plus ProteinTM Dual Xtra Prestained Protein Standards (Biorad, Hercules, CA).

\section{Production of canary seed peptides (CSP)}

Proteolysis was carried out following the procedure described by Urbizo-Reyes et al. (2019). Briefly, canary seed powder was diluted to obtain (22.5 mg of protein/ $\mathrm{mL}$ ) and homogenized using a Sorvall Omni Mixer (Norwalk, CT, U.S.A). The sample $\mathrm{pH}$ was adjusted to pH 8 with $2 \mathrm{M} \mathrm{NaOH}$ and preheated to $50 \pm 3^{\circ} \mathrm{C}$ for optimal protease conditions. The sample was hydrolyzed for a period of $4 \mathrm{~h}$ with Alcalase $3 \%(\mathrm{w} / \mathrm{w})$. Hydrolysis was stopped by pasteurization $95 \pm 3{ }^{\circ} \mathrm{C}$ for $15 \mathrm{~min}$. The sample was cooled and centrifuged $(17,636 \times \mathrm{g}$ for $15 \mathrm{~min})$ (Avanti J-26S Centrifuge, Beckman-Coulter INC. CA, USA). The supernatant was collected and referred to as canary seed peptides (CSP). CSP were frozen at $-80^{\circ} \mathrm{C}$ for $12 \mathrm{~h}$ and freeze-dried using a Labconco FreeZone Plus $2.5 \mathrm{~L}$ cascade benchtop freeze dry system (Labconco Corp., Kansas City, MO). The CSP powder was stored at $4 \pm 1{ }^{\circ} \mathrm{C}$ until use.

\section{Degree of hydrolysis (DH)}

DH was calculated following the methodology of AdlerNissen with slight modifications by Liceaga-Gesualdo and Li-Chan (1999), measuring spectrophotometrically the color formed by free amino groups reacting with Trinitrobenzenesulforonic acid (TNBS). The DH was defined as a percent ratio of the number of peptide bonds broken $(h)$ to the total number of peptide bonds per unit weight $\left(h_{t o t}\right)$. The $h_{t o t}$ was calculated experimentally using the fully hydrolyzed canary seed protein, which was determined to be (7.28). DH was calculated using equation [1].

$$
\text { Degree of hydrolysis }(\%)=100 \times \frac{h}{h t o t}
$$

\section{Fractionation of canary seed peptides}

CSP were fractionated according to the method proposed by Farvin et al. (2016). Briefly, CSP were reconstituted to a concentration of $10 \mathrm{mg} / \mathrm{mL}$ in distilled water. CSP solution was ultra-filtrated using $3 \mathrm{kDa}$ and $10 \mathrm{kDa}$ molecular-weight-cut-off membranes (Sigma Aldrich, St. Louis, MO, USA), which resulted in three CSP fractions $<3 \mathrm{kDa}, 3-10 \mathrm{kDa}$, and $>10 \mathrm{kDa}$. The CSP fractions were freeze-dried, as described above.

\section{Angiotensin converting enzyme (ACE) inhibitory activity}

The ACE-inhibitory activity was measured, according to Urbizo-Reyes et al. (2019). CSP fractions were dissolved in phosphate buffer (100 mM, pH 8.3) with $300 \mathrm{mM}$ sodium chloride. Aliquots $(25 \mu \mathrm{L})$ of CSP solutions were added to $25 \mu \mathrm{L}$ of the substrate hippuryl-L-histidyl-Lleucine (HHL) and incubated at $37^{\circ} \mathrm{C}$ for $4 \mathrm{~min}$. Then, aliquots $(80 \mu \mathrm{L})$ of human-ACE $(50 \mathrm{mU})$ were added to initiate the reaction, followed by incubation at $37^{\circ} \mathrm{C}$ in a water bath with constant stirring for $2 \mathrm{~h}$. The reaction was terminated by adding $50 \mu \mathrm{L}$ of $1 \mathrm{M} \mathrm{HCl}$; then the solution was filtered using a $0.22 \mu \mathrm{m}$ nylon filter, and $100 \mu \mathrm{L}$ of (1:1) solution of acetonitrile with $1 \%(\mathrm{v} / \mathrm{v})$ Trifluoroacetic acid (TFA) and distilled water 1\% TFA was added before measurement. A control reaction was performed using $25 \mu \mathrm{L}$ of buffer instead of the inhibitor (CSP). Hippuric acid (HA) was quantified using highpressure liquid chromatography (HPLC) (Model 600E, Waters Corporation, Milford MA) with a C18 analytical column (YMC Pack ODS AM 12505-2546WT, YMC America, Inc., Allentown, PA, USA). Percentage inhibition was calculated using equation [2]

$$
\text { ACE inhibition }(\%)=\left[1-\frac{\text { A_inhibitor }}{A \_ \text {control }}\right] \times 100
$$

where, $A \_$inhibitor and $A \_$control represent the relative areas (A) with and without inhibitor of the HA peaks. The half maximal inhibitory concentration $\left(\mathrm{IC}_{50}\right)$ determined the potency of the samples towards ACE inhibitory activity. $\mathrm{IC}_{50}$ was expressed in $\mathrm{mg}$ of protein per $\mathrm{mL}$. $\mathrm{IC}_{50}$ calculations were determined at four different CSP concentrations $(0.05,0.5,1$, and $5 \mathrm{mg} / \mathrm{mL})$ in triplicate.

\section{Lipase inhibition}

The effect of CSP fractions on lipase inhibition was measured using Lecitase ${ }^{\bullet}$ Ultra Novozymes as a source of lipolytic enzyme and 4-methylumbelliferyl oleate as a substrate. Briefly, $50 \mu \mathrm{L}$ of the substrate $(1 \mathrm{mM})$ dissolved in Tris buffer $(13 \mathrm{~mm}$ Tris- $\mathrm{HCl}, 150 \mathrm{~mm} \mathrm{NaCl}$, 
and $1.3 \mathrm{~mm} \mathrm{CaCl} 2, \mathrm{pH} 8.0$ ) were pre-incubated with $25 \mu \mathrm{L}$ of sample for $10 \mathrm{~min}$. Then, $25 \mu \mathrm{L}$ of lipase $(1000$ $\mathrm{U})$ was added, and the reaction was carried out for $1 \mathrm{~h}$. The production of 4-methylumbelliferone was measured using a Multiskan ${ }^{\text {tm }}$ FC Microplate Photometer (Waltham, MA, USA) with excitation and emission wavelength of $355 \mathrm{~nm}$ and $460 \mathrm{~nm}$, respectively. Finally, lipase inhibition was calculated using the equation [3].

$$
\text { Lipase inhibition }(\%)=\left[1-\frac{(\text { Abs sample }- \text { Abs negative control })}{(\text { Abs positive control }- \text { Abs negative control })}\right] \times 100
$$

\section{Dipeptidyl peptidase-IV (DPP-IV) inhibitory activity}

The DPP-IV inhibitory activity of CSP was determined following the method by Hall et al. (2018). CSP samples were dissolved in $100 \mathrm{mM}$ Tris- $\mathrm{HCl}$ buffer ( $\mathrm{pH} \mathrm{8.0)}$ to a final concentration of $1.25 \mathrm{mg} / \mathrm{mL}$. Sample aliquots $(25 \mu \mathrm{L})$ were pipetted and pre-incubated in a 96-well microplate with $25 \mu \mathrm{L}$ of substrate Gly-Pro p-nitroanilide hydrochloride $(6 \mathrm{mM})$ at $37^{\circ} \mathrm{C}$ for $10 \mathrm{~min}$. The colorimetric reaction was initiated by adding $50 \mu \mathrm{L}$ of human DPP-IV $(4.5 \mathrm{U} / \mathrm{mL})$, followed by incubation at $37^{\circ} \mathrm{C}$ for $60 \mathrm{~min}$. The reaction was stopped by adding $100 \mu \mathrm{L}$ of 1 $M$ sodium acetate buffer ( $\mathrm{pH} 4.0$ ). The absorbance of released p-nitroanilide was measured at $405 \mathrm{~nm}$ using a Multiskan $^{\text {tu }}$ FC Microplate Photometer (Waltham, MA, USA). Sample absorbance was corrected by subtracting blanks in which DPP-IV was replaced with Tris-HCl buffer (100 mM, pH 8.0). The positive control (no inhibitor) used the buffer instead of the CSP. For negative control (no DPPIV activity), the buffer was used instead of the DPP-IV solution. Percent of DPP-IV inhibition was calculated using equation [4].

$$
D P P-I V \text { inhibition }(\%)=1-\left[\frac{\text { Abs sample }- \text { Abs sample blank }}{\text { Abs positive control }- \text { Abs negative control }}\right]
$$

\section{a-Glucosidase inhibitory activity}

The inhibition of $\alpha$-glucosidase activity was determined following the methodology proposed by Sultana et al. (2020). First, $\alpha$-glucosidase was extracted by solubilizing $300 \mathrm{mg}$ of rat intestinal acetone powder in $9 \mathrm{~mL}$ sodium chloride solution $(0.9 \%, \mathrm{w} / \mathrm{v})$ and vortex vigorously for $10 \mathrm{~min}$. Then, the solution was centrifuged at $12,500 \times \mathrm{g}$ for $5 \mathrm{~min}$, the supernatant recovered and used as a source of $\alpha$-glucosidase $(8.33 \mathrm{mg} / \mathrm{L})$. Briefly, a $50 \mu \mathrm{L}$ aliquot of CSP fraction suspended in $0.1 \mathrm{M}$ sodium phosphate buffer ( $\mathrm{pH}$ 6.9) was pipetted into a 96-well microplate, with $50 \mu \mathrm{L}$ of $\alpha$-glucosidase, followed by a pre-incubation for $10 \mathrm{~min}$ at $37^{\circ} \mathrm{C}$. Then, $100 \mu \mathrm{L}$ of 4 nitrophenyl $\alpha$-D-glucopyranoside $(5 \mathrm{mM})$ was added, and the inhibition was calculated spectrophotometrically using Multiskan ${ }^{\text {Tax }}$ FC Microplate Photometer (Waltham, MA, USA) reading the absorbance at $405 \mathrm{~nm}$ for $30 \mathrm{~min}$. Acarbose was used as a reference for the analysis. Finally, the $\%$ inhibition was calculated using equation [5].

$$
\left.\alpha-\text { glucosidase inhibition }(\%)=100 \times\left[\frac{\text { Abs Control }(\text { no inhibitor })-\text { Abs Sample }}{(\text { Abs Control }(\text { no inhibitor })}\right)\right]
$$

\section{2-Diphenyl-2-picrylhydrazyl (DPPH) radical scavenging activity}

The antioxidant activity against DPPH was measured following the methodology reported by Hall et al. (2018). Briefly, CSP sample aliquots $(100 \mu \mathrm{L})$ were pipetted into a 96-well plate with $100 \mu \mathrm{L}$ ethanol (99.5\%) and $25 \mu \mathrm{L}$ $\mathrm{DPPH}(0.05 \%$, in ethanol w/v). The solution was incubated for $30 \mathrm{~min}$ at room temperature under dark conditions, and the absorbance read at $550 \mathrm{~nm}$ using a Multiskan $^{\text {TM }}$ FC Microplate Photometer (Waltham, MA, USA). The radical reduction was expressed in $\mu \mathrm{M}$ of Trolox equivalent/mg of protein. Finally, the results were analyzed performing a correction using the sample blank containing $25 \mu \mathrm{L}$ ethanol instead of DPPH. Results were reported in Trolox equivalent (TE/mg of protein).

\section{2,2'-azino-bis (3-ethylbenzothiazoline-6-sulphonic acid) radical scavenging activity (ABTS)}

The ABTS radical scavenging activity was determined according to Ketnawa and Liceaga (2017) with some modifications. A solution of $7 \mathrm{mM}$ of ABTS was prepared in $2.45 \mathrm{mM}$ of potassium persulphate and incubated at room temperature for $16 \mathrm{~h}$. After incubation, the ABTS stock solution was diluted with distilled water to obtain an absorbance at $734 \mathrm{~nm}$ of $0.700 \pm 0.02$. A CSP sample aliquot $(10 \mu \mathrm{L})$ was mixed with $290 \mu \mathrm{L}$ ABTS solution and incubated in the dark at $30^{\circ} \mathrm{C}$ for 10 $\mathrm{min}$, followed by reading the absorbance at $734 \mathrm{~nm}$. The ABTS scavenging activity was expressed as $\mathrm{mM}$ Trolox equivalent (TE)/mg sample.

\section{Statistical analysis}

The results in this study were analyzed using a complete randomized design with a Duncan separation of means $p<0.05$ by the statistical software SAS 9.4 (Cary, NC, USA). Results were reported as mean \pm standard deviation (SD) of triplicate determinations.

\section{Results and discussion}

\section{Proximate composition}

The composition of canary seeds and defatted canary seed powder is shown in Table 1 . The protein, carbohydrate, lipids, and ash content obtained in this study were within the range of those reported by Abdel-Aal 
et al. (2010). Canary seed is mainly composed of carbohydrates (starch) and protein, making the high protein content of canary seed (15.63\%) excel from other cereals, including wheat (11.28\%), rye $(7.13 \%)$, barley (7.66\%), and oats (8.07\%) (Schalk et al. 2017; Mason et al. 2018). In this study, implementing a mechanical oil extraction proved to be efficient in removing most of the lipids (yield $=72.28 \%$ ) from the seeds. This method is also more environmentally friendly as it eliminates the use of solvents such as isopropanol, hexane, petroleum ether, and ethanol. Urbizo-Reyes et al. (2019), reported similar observations, where chia seed oil was effectively separated using a mechanical oil press. Hence, this oil extraction methodology could serve as a green separation step in industrialscale applications to obtain canary seed components (i.e., starch, protein, and oil).

\section{Isolation of storage proteins}

It is known that seeds have diverse protein types for different biological purposes (e.g., hydrolysis of carbohydrates and proteins, protecting agents, or structural support for plant growth) (Sá et al. 2020). When studying the nutritional and nutraceutical properties, we are most interested in the storage proteins since they account for an estimated 50\% of the protein content in seeds, legumes, and pulses (Shewry and Halford 2002). A characterization using the Osborne classification is perhaps one of the most useful ways to classify storage proteins in seeds (Nadathur et al. 2017). In this study, the Osborne classification indicated that canary seed proteins were primarily composed of prolamins $(54.07 \pm$ $1.8 \%)$, followed by glutelins $(32.19 \pm 3.18 \%)$, globulins (7.89 $\pm 0.40 \%)$, and albumins $(5.97 \pm 0.52 \%)$ (Fig. 1). Prolamins are the main storage protein in canary seeds as well as in other common grasses, including wheat (gliadin), barley (hordein), maize (zein), rye (secalin), and oat (avenin) (González-Pérez and Arellano 2009). The prolamin content obtained in this study was similar to the one reported by Valverde et al. (2017) but higher than

Table 1 Proximate composition of canary seed and defatted canary seed (wet basis)

\begin{tabular}{lll}
\hline Component & $\begin{array}{l}\text { Whole canary } \\
\text { seed } \\
\mathbf{( g / 1 0 0 ~} \mathbf{~})\end{array}$ & $\begin{array}{l}\text { Defatted canary } \\
\text { seed } \\
\mathbf{( g / 1 0 0 ~} \mathbf{~})\end{array}$ \\
\hline Moisture & $12.13 \pm 0.16$ & $8.80 \pm 0.21$ \\
Lipids & $5.24 \pm 0.10$ & $1.45 \pm 0.04$ \\
Protein & $15.63 \pm 0.38$ & $15.77 \pm 0.13$ \\
Ash & $4.40 \pm 0.20$ & $4.16 \pm 0.13$ \\
Carbohydrate & $62.88 \pm 0.29$ & $69.82 \pm 0.20$ \\
(by difference) & & \\
\hline
\end{tabular}

Values are mean \pm standard deviation of triplicate determinations. the one reported by Estrada-Salas et al. (2014). This could be attributed to the higher extraction yield obtained in our study by using isopropanol over ethanol during the prolamin extraction process, in addition the decrease in the amount of solvent used by implementing a mechanical oil extraction step, could play a role in the preservation of this protein fraction on the defatted flour. The globulin fraction was composed of globulins $7 \mathrm{~s}(4.44 \pm 0.35 \%)$ and globulins $11 \mathrm{~s}(3.45 \pm 0.46 \%)$. In the case of glutelins, our results are in accordance with those reported by Estrada-Salas et al. (2014) and Valverde et al. (2017).

From the SDS-PAGE results (supplemental material 1), the isolated storage protein fractions showed to have high purity with no perceivable contamination. Canary seeds showed to be a high source of hydrophobic protein fractions (prolamin and glutelins). Therefore, research can be focused on the isolation of these proteins, as it is known that hydrophobic proteins (e.g., zein and gliadin) can serve as nanoparticle forming compounds, and hydrophobic peptides liberated from such fractions can exhibit high antihypertensive activity (Marambe and Wanasundara 2012; Malekzad et al. 2018).

\section{Degree of hydrolysis (DH) of canary seed peptides}

The DH indicates the percentage of peptide bonds cleaved, particularly under enzymatic hydrolysis (Adler-Nissen 1986). Variating the DH will directly impact the peptide size and the hydrolysates' free-amino acid composition (Balti et al. 2010). A low DH (< $10 \%)$ has been an important parameter used to control the functional properties of protein hydrolysates in food matrices (Zhang et al. 2019). In contrast, higher DH (>10\%) have been principally associated with modulation and improvement of biological activities and processes (Balti et al. 2010). In this study, $\mathrm{DH}$ higher than $10 \%$ was achieved after $60 \mathrm{~min}$ of hydrolysis (Fig. 2), and the highest DH (30.2 $\pm 0.85 \%)$ was obtained at $4 \mathrm{~h}$. For this reason, the CSP with the highest DH was used to evaluate the biological activities. To our current knowledge, no other study has evaluated the DH and production of canary seed peptides using Alcalase. Peptides from canary seed have been generated using trypsin from the porcine pancreas under simulated gastrointestinal digestion; however, the DH achieved was not reported (Rajamohamed et al. 2013; Estrada-Salas et al. 2014; Valverde et al. 2017). As with other plant proteins, canary seed proteins required a long hydrolysis time $(4 \mathrm{~h})$ to achieve a high $\mathrm{DH}(30.2 \pm 0.85 \%)$. Canary seed proteins are known to have $43 \%$ more content of sulfur-containing amino acids (e.g., cysteine and methionine) than other cereals such as wheat (AbdelAal et al. 1997). Hence, the high content of sulfur- 


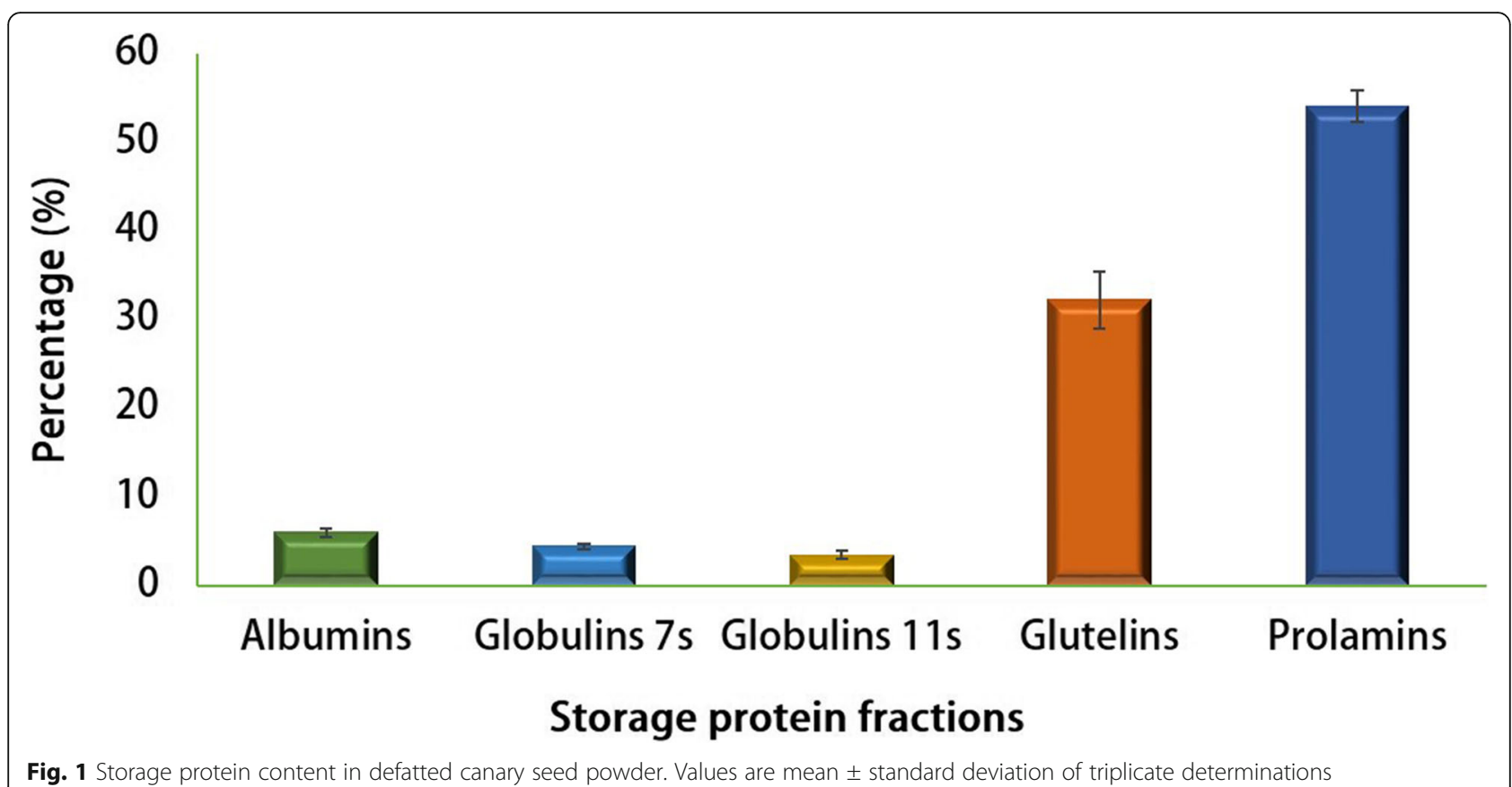

containing amino acids promotes the disulfide-bridges formation and, consequently, a highly packed tertiary structure (Bai et al. 2016). This highly packed structure causes protein hydrolysis to take a longer time in order to increase DH significantly since peptide bonds are often encrypted and not easily accessible to the proteases. The DH reported in this study (Fig. 2) was higher than that reported for wheat, rice, and potato when hydrolyzed for $3 \mathrm{~h}$ using Alcalase with 9.9, 9.6, 11.4\% DH, respectively (Tschiersch et al. 2010).
Estrada-Salas et al. (2014) showed that long digesting times $(>6 \mathrm{~h})$ using trypsin decreased the presence of protein fractions larger than $10 \mathrm{kDa}$. This observation aligns with our results, where hydrolysis for $4 \mathrm{~h}$ resulted in more peptide bonds cleaved $(\sim 30 \% \mathrm{DH})$. Finally, CSP production resulted in the liberation of two by-products (oil and fiber) with potential economic value. For instance, canary seed oil can be used as a source of unsaturated fat to fortify foods and beverages (Abdel-Aal et al. 2010), and the canary seed fiber can have

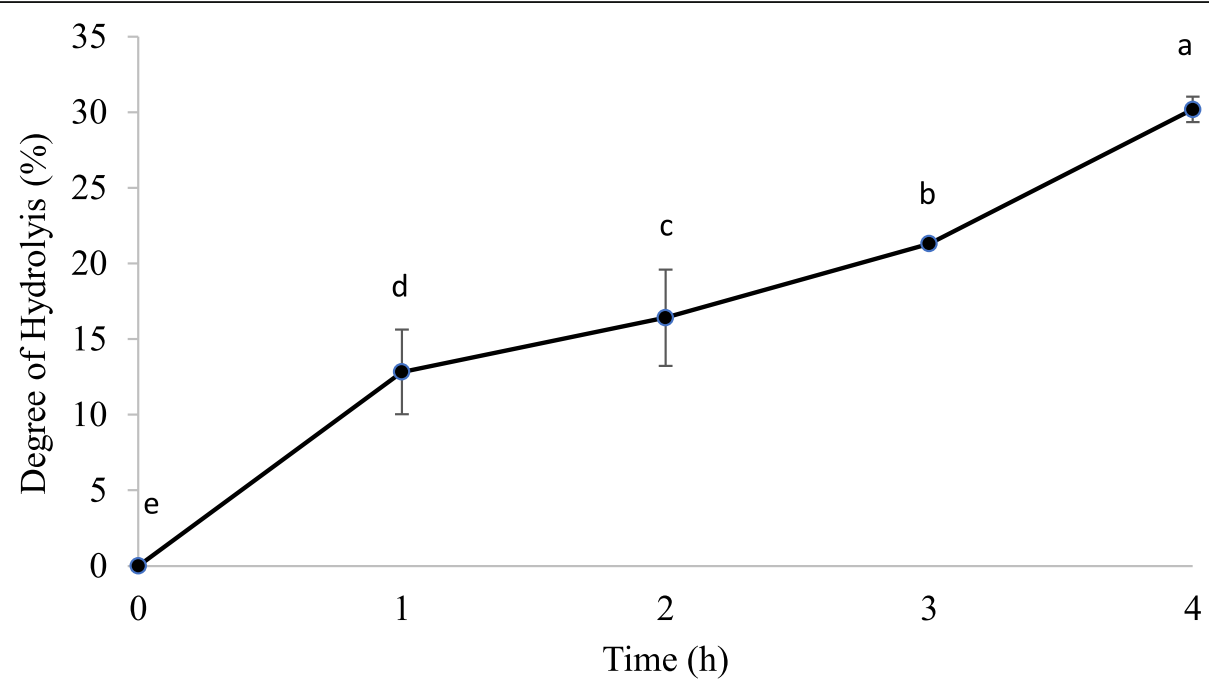

Fig. 2 Degree of hydrolysis (\%) of canary seed protein over time, using a commercial protease (alcalase). Data points and error bars represent mean \pm standard deviation of triplicate determinations. Different letters (a-e) indicate significant differences $(p<0.05)$ between degree of hydrolysis values 
applications as a source of dietary fiber in food formulation (Cogliatti 2012; Basile et al. 2020).

\section{ACE inhibitory activity}

ACE raises blood pressure by converting angiotensin-I released from the hydrolysis of angiotensinogen by renin into a precursor of vasoconstriction angiotensin II (Pihlanto-Leppälä 2000). Synthetic ACE inhibitors have been utilized as potent oral antihypertensive drugs for years (Bakhle 2020); however, research has identified that plant constituent (e.g., peptides, terpenoids, alkaloids, tannins, proanthocyanidins, and flavonoids) can serve as a natural source of ACE inhibitors (R. Kumar et al. 2010). Small molecular weight peptides, for instance, have demonstrated a strong inhibitory capacity compared to other natural macromolecules (Alcaide-Hidalgo et al. 2020). In the present study, canary seed peptides showed high inhibitory activity, with small molecular weight fractions $(<3 \mathrm{kDa}$ and $3-10 \mathrm{kDa})$ having a higher inhibitory activity $(p<0.05)$ compared to the $>10 \mathrm{kDa}$ fraction (Table 2). These results reiterate the importance of peptide size in the capacity of ACE inhibition. The $\mathrm{IC}_{50}$ for canary seed peptides in this study was 26.75 and $31.73 \mu \mathrm{g} / \mathrm{mL}$ for the $<3 \mathrm{kDa}$ and $3-$ $10 \mathrm{kDa}$ fractions, respectively. Although these values were not as low as the $\mathrm{IC}_{50}$ reported for Captopril $(0.02 \mu \mathrm{g} / \mathrm{mL})$, our results were 10 -fold lower from those previously reported for canary seed peptides, ranging between 217 and $332 \mu \mathrm{g} / \mathrm{mL}$ (Estrada-Salas et al. 2014; Valverde et al. 2017). The values were also lower than those reported for ultra-filtered $(<3 \mathrm{kDa})$ canary seed peptides $\left(\mathrm{IC}_{50}=0.33 \mathrm{mg} / \mathrm{mL}\right)$, chia seed peptides $\left(\mathrm{IC}_{50}=\right.$ $0.42 \mathrm{mg} / \mathrm{mL}$ ), wheat protein hydrolysates $\left(\mathrm{IC}_{50}=0.42-\right.$ $2.22 \mathrm{mg} / \mathrm{mL}$ ), and similar to those reported for oats $\left(\mathrm{IC}_{50}=0.030-0.050 \mathrm{mg} / \mathrm{mL}\right.$ ) (Cheung et al. 2009; Jia et al. 2010; Mason 2019; Urbizo-Reyes et al. 2019). In our study, the use of Alcalase, an endo-protease, influenced the type of peptides released. Mäkinen et al. (2012) showed that hydrolyzing rapeseed protein with Alcalase lead to an increase in hydrophobic peptide fractions, known to contribute significantly to their ACEinhibitory activity. It has been reported that small structural conformation bioactive peptides could have contributed to enhanced bioactivity since tri- and tetrapeptides showed to be most efficient in ACE inhibition, which can explain, in part, the results obtained in the present study with of CSP. Additionally, it is known that the presence of aliphatic amino acids such as alanine, leucine isoleucine in the $\mathrm{N}$-terminal could enhance the overall affinity of a peptide to ACE active site (Krichen et al. 2018). Nevertheless, more research is needed to understand the peptide sequence and CSP length with high ACE inhibitory capacity. Thus, these results indicate the high potential of CSP as natural compounds to act as ACE-inhibitors.

\section{Lipase inhibition}

The overall prevalence of overweight and obesity has doubled since 1980, and currently, about $33 \%$ of the world's population falls into obese or overweight categories (Chooi et al. 2019). Obesity is a disorder of lipid metabolism, and modulating enzymes involved in this process can be essential to develop anti-obesity compounds and drugs (Birari and Bhutani 2007). Pancreatic lipase will hydrolyze $50-70 \%$ of the total dietary sources of fat, including triacylglycerol and phospholipids (Birari and Bhutani 2007). Research has shown the ability of phytochemicals to inhibit pancreatic lipase (Birari and Bhutani 2007). In the case of bioactive peptides, a gap in research arises as the use of peptides to inhibit this pancreatic enzyme is limited to a few sources (e.g., fish, brewer's spent grain, and yellow field pea) (Liu et al. 2013; Awosika and Aluko 2019; Garzón et al. 2020). A study by Perez Gutierrez et al. (2016) reported that canary seeds $(100 \mu \mathrm{g} / \mathrm{mL})$ extracted using hexane and methanol showed inhibitory activity towards enzymes linked to obesity. However, the bioactive compounds were not identified and bioactivity was attributed to a group of lipase inhibitors such as bioactive phytochemicals. To best of our knowledge, this is the first report that canary seed peptides, derived from commercial enzymatic proteolysis, have lipase inhibitory capabilities. In this study, CSP $<3$ and $3-10 \mathrm{kDa}$ fractions showed higher $(p<0.05)$ lipase inhibitory activity than the $>10$ $\mathrm{kDa}$ fraction (Table 2). These values were lower than the ones reported for yellow field pea protein hydrolyzed with Alcalase $\left(\mathrm{IC}_{50}=3.98 \pm 0.4 \mathrm{mg} / \mathrm{mL}\right.$ ) (Awosika and Aluko 2019); but higher than the ones obtained from thermally treated millet grain protein $\left(\mathrm{IC}_{50}=0.03 \mathrm{mg} /\right.$ $\mathrm{mL}$ ) (Jakubczyk et al. 2019) and the synthetic inhibitor

Table 2 Bioactive properties of canary seed peptide fractions, including enzyme inhibition $\left(\mathrm{IC}_{50}\right)$ and antioxidant activities

\begin{tabular}{lllllll}
\hline CSP fraction & $\begin{array}{l}\text { ACE inhibition } \\
\mathbf{I C}_{\mathbf{5 0}}(\mathbf{m g} / \mathbf{m L})\end{array}$ & $\begin{array}{l}\text { DPP-IV inhibition } \\
\mathbf{I C}_{\mathbf{5 0}}(\mathbf{m g} / \mathbf{m L})\end{array}$ & $\begin{array}{l}\text { Lipase inhibition } \\
\mathbf{I} \mathbf{C}_{\mathbf{5 0}}(\mathbf{m g} / \mathbf{m L})\end{array}$ & $\begin{array}{l}\text { a-glucosidase inhibition } \\
\mathbf{I} \mathbf{C}_{\mathbf{5 0}}(\mathbf{m g} / \mathbf{m L})\end{array}$ & $\begin{array}{l}\text { DPPH } \\
(\boldsymbol{\mu m o l ~ T E} / \mathbf{m g})\end{array}$ & $\begin{array}{l}\text { ABTS } \\
(\boldsymbol{\mu m o l ~ T E} / \mathbf{m g})\end{array}$ \\
\hline$<3 \mathrm{kDa}$ & $0.026 \pm 0.003 \mathrm{a}$ & $1.27 \pm 0.11 \mathrm{a}$ & $2.15 \pm 0.07 \mathrm{a}$ & $1.15 \pm 0.05 \mathrm{a}$ & $150.66 \pm 5.26 \mathrm{a}$ & $813.33 \pm 2.34 \mathrm{a}$ \\
$3-10 \mathrm{kDa}$ & $0.032 \pm 0.001 \mathrm{a}$ & $1.60 \pm 0.23 \mathrm{a}$ & $2.27 \pm 0.15 \mathrm{a}$ & $0.82 \pm 0.06 \mathrm{a}$ & $134.22 \pm 11.58 \mathrm{a}$ & $520.92 \pm 7.55 \mathrm{~b}$ \\
$>10 \mathrm{kDa}$ & $0.069 \pm 0.001 \mathrm{~b}$ & $2.99 \pm 0.64 \mathrm{~b}$ & $2.80 \pm 0.13 \mathrm{~b}$ & $1.64 \pm 0.25 \mathrm{~b}$ & $102.82 \pm 13.48 \mathrm{~b}$ & $693.71 \pm 8.25 \mathrm{C}$ \\
\hline
\end{tabular}

Values represent mean \pm standard deviation of triplicate determinations. Different letters $(\mathrm{a}-\mathrm{c})$ within columns indicate significant difference $(p<0.05)$ between canary seed peptide (CSP) fractions. 
Orlistat $\left(\mathrm{IC}_{50}=2.73 \mu \mathrm{g} / \mathrm{mL}\right)$ (Gupta et al. 2015). Research regarding lipase inhibition by bioactive peptides is limited, with the exact mechanism not completely understood. Nevertheless, a recent study by Mudgil et al. (2018) reported that small molecular weight peptides might interrupt the N-terminal flap of lipase, which makes the active site accessible to the substrate by forming a functional oxyanion hole and generating an interface-binding site. It was also shown that peptides with a predominant content of hydrophobic amino acid residues tend to interact strongly with the three binding sites of lipase (Ser153, Phe216, and His264). Prolamin fractions are known to be rich in hydrophobic residues, and thus a high content of this protein fraction in canary seed (Fig. 1) could have contributed to the high lipase inhibition activities observed in our study. Jakubczyk et al. (2019) reported that peptides derived from prolamin fractions of millet seeds had the highest inhibition against pancreatic lipase than other storage protein fractions. Now that we have demonstrated that a controlled, commercial enzymatic hydrolysis is capable of generating peptide inhibitors towards enzymes linked to obesity, more research on CSP fraction's potential use as natural anti-obesity compounds for managing overweight and obesity is needed to understand the underlying mechanism of the peptide composition, mode of inhibition by which these peptides inhibit lipase, and their effect in cellular and in vivo models.

\section{Dipeptidyl peptidase-IV (DPP-IV) inhibition}

Type 2 diabetes is associated with insulin deficiency caused by pancreatic $\beta$-cell dysfunction and insulin resistance in specific organs (Chatterjee et al. 2017). Insulin is secreted as a response to the liberation of glucagon-like peptide-1 (GLP-1), which is known to increase insulin secretion, decrease glucagon secretion, decrease hepatic glucose output, and delay gastric emptying, and increase overall satiety (Nauck and Meier 2016). Hence, the protease DPP-IV is known to degrade GLP-1 by cleaving its N-terminal dipeptide (His-Ala) and cause a loss in its insulinotropic activity (Drucker 2007). Studies have shown that plant-derived peptides can exhibit DPP-IV inhibitory activity (Nongonierma and FitzGerald 2015). In the case of CSP, the smallest fractions $(<3 \mathrm{kDa}$ and $3-10 \mathrm{kDa})$ showed higher $(p<$ 0.05) DPP-IV inhibitory activity with $\mathrm{IC}_{50}=1.27$ and $1.60 \mathrm{mg} / \mathrm{mL}$, respectively compared to the $>10 \mathrm{kDa}$ CSP fraction (Table 2). These results can be due to the lower molecular weight peptides present in these fractions since it is well reported that their smaller molecular size can facilitate their access to target sites of the enzyme or recognition motifs sites located on the enzyme surface (Aguilar-Toalá and Liceaga 2020). For instance, peptides with 4-13 amino acids have shown specific homologies of inhibition where hydrophobic amino acids at the Nterminal and proline at the penultimate position of the peptide chain are specific features that contribute dramatically to bioactive peptides' ability to bind to DPP-IV active site (Nongonierma et al. 2018). Further research is needed to identify specific sequences that offer this inhibitory activity by CSP. Nevertheless, these results are comparable to those reported for amaranth flour $\left(\mathrm{IC}_{50}=\right.$ $1.10 \mathrm{mg} / \mathrm{mL})$, hemp $\left(\mathrm{IC}_{50}=3.0 \mathrm{mg} / \mathrm{mL}\right)$, Bambara bean $\left(\mathrm{IC}_{50}=1.0 \mathrm{mg} / \mathrm{mL}\right)$, and rice bran $\left(\mathrm{IC}_{50}=2.30 \mathrm{mg} / \mathrm{mL}\right)$ protein hydrolysates (Hatanaka et al. 2012; VelardeSalcedo et al. 2013; Nongonierma and FitzGerald 2015; Mune et al. 2018), but much higher than the commercial drug Sitagliptin $\left(\mathrm{IC}_{50}=20.36 \mathrm{ng} / \mathrm{mL}\right.$ ) (Bower et al. 2014). This study's results also align with those reported by Estrada-Salas et al. (2014), where non-fractionated canary seed protein hydrolysates reported a $43.4 \%$ DPP-IV inhibition with a protein concentration of $1.4 \mathrm{mg} / \mathrm{mL}$.

\section{a-Glucosidase inhibition}

The enzyme $\alpha$-glucosidase is an exo-type carbohydrase that catalyzes the liberation of $\alpha$-glucose from the nonreducing end of the substrate (Kumar et al. 2011). The inhibition of this enzyme decreases the hydrolytic cleavage of oligosaccharides and therefore causes a delay in carbohydrate digestion throughout the rest of the digestive system. These results in a decrement in the postprandial rise of glucose and prevents diabetic-related complications. The most common plant constituents that exhibit $\alpha$-glucosidase inhibitory activity include flavonoids, alkaloids, phenolics, curcuminoids, terpenoids, and anthocyanins (Kumar et al. 2011). However, Peptides have been lately included in this list, with peptides from sardine, egg white, and egg albumin showing high activity against the enzyme (Roskar et al. 2015). As with the other bioactivities evaluated, CSP fractions $(<3 \mathrm{kDa}$ and $3-10 \mathrm{kDa})$ exhibited the highest $(p<0.05)$ inhibitory capacity $\left(\mathrm{IC}_{50}=1.15\right.$ and $0.82 \mathrm{mg} / \mathrm{mL}$, respectively) compared to the $>10 \mathrm{kDa}$ fraction (Table 2). This is also the first time CSP has demonstrated inhibitory capacity towards $\alpha$-glucosidase, highlighting new possibilities where these peptides can contribute to improving human health. Poovitha and Parani (2016) reported that plant bioactive peptides with $\alpha$-glucosidase mainly act by competitive inhibition over the enzyme's active site. Additionally, it has been shown that smaller peptides $(2-8$ amino acids) with a predominant content of hydrophobic amino acids (leucine and proline) can contribute to the inhibitory activity over $\alpha$-glucosidase (Wang et al. 2019). In this aspect, Ren et al. (2016) found similar results, where high content of hydrophobic amino acids enhanced the inhibitory activity of hemp peptides to bind $\alpha$-glucosidase's active site, and the peptides with a $\mathrm{DH}$ higher than $9.68 \%$ exhibited increased inhibitory 
activity. It can be hypothesized that the high content of hydrophobic prolamin fractions in the defatted canary seed protein and the high $\mathrm{DH}(30.2 \%)$ reported in this study, positively contributed to the $\alpha$-glucosidase inhibitory capacity. The enzyme inhibition values achieved by the low molecular weight fractions used in this study were better than those reported for quinoa $\left(\mathrm{IC}_{50}=1.45-\right.$ $1.81 \mathrm{mg} / \mathrm{mL}$ ) (Wang et al. 2019) and soy $\left(\mathrm{IC}_{50}=4.94 \mathrm{mg} /\right.$ $\mathrm{mL}$ ) (Vilcacundo et al. 2017). Our results are also similar to those obtained for purified fractions of rice protein hydrolysates produced with Alcalase $\left(\mathrm{IC}_{50}=0.21-5.25\right.$ $\mathrm{mg} / \mathrm{mL}$ ) and Egyptian cucumber (Luffa cylindrica) seed protein hydrolysates $\left(\mathrm{IC}_{50}=0.80 \mathrm{mg} / \mathrm{mL}\right.$ ) (Arise et al. 2019; Ren et al. 2016), but higher than those for bitter gourd (Momordica charantia L.) $\left(\mathrm{IC}_{50}=0.29 \mathrm{mg} / \mathrm{mL}\right.$ ) (Poovitha and Parani 2016) and commonly used synthetic inhibitor acarbose $\left(\mathrm{IC}_{50}=0.10 \mathrm{mg} / \mathrm{mL}\right.$ ) (Varghese et al. 2013). These preliminary in vitro results for DPPIV and $\alpha$-glucosidase inhibition demonstrate their antidiabetic potential and their possible use in decreasing the postabsorptive spike in glucose uptake in the bloodstream. However, further research must look into the mechanism of action and peptide conformation in the CSP to act against $\alpha$-glucosidase.

\section{Antioxidant activity}

The rise in free radicals causes damage in cells and leads to a pathological condition called oxidative stress. Oxidative stress is associated with impairment in a wide range of molecular species such as lipids, proteins, and nucleic acids and contributes directly to developing inflammatory diseases, ischemic diseases, certain cancers, and accelerated aging (Lobo et al. 2010). It is known that the antioxidant activity of protein hydrolysates can help cope with the effects of oxidative stress (Sarmadi and Ismail 2010). The results obtained in this study (Table 2) showed that CSP might serve as antioxidant agents for biological protection and/or food preservation. Overall, higher antioxidant activity was observed for the $<3 \mathrm{kDa}$ and $3-10 \mathrm{kDa}$ CSP fractions. In this context, lower molecular weight peptides derived from other plant seeds have been reported as effective antioxidants. For example, Ngoh and Gan (2016) found that that antioxidant peptide fractions $(<3 \mathrm{kDa})$ derived from pinto bean (Phaseolus vulgaris cv. pinto) hydrolysates had $42.2 \%$ ABTS inhibition compared with the high molecular weight fractions $(>100,50-100,30-50,10-30$, and $3-$ $10 \mathrm{kDa}$ ). In similar studies, the $<1$ and $<3 \mathrm{kDa}$ peptide fractions from canola (Brassica sp.) meal protein (Alashi et al. 2014) and sweet potato (Ipomoea batatas var. Mixuan 1) protein (Zhang et al. 2014) exhibited the highest antioxidant activity compared to the other fractions with higher molecular weight peptides. Thus, the low molecular weight of peptides continues to play an essential role in the enhancement of the antioxidant properties, compared with other higher molecular weight peptides, because it increases interaction with ROS or their accessibility to cellular targets such as polyunsaturated fatty acid chains of biological membranes (Zou et al. 2016). On the other hand, the inhibition of the free radical DPPH was higher than those reported for rice $(80.18 \mu \mathrm{M}$ Trolox equivalent/g sample), date seed $(0.36 \mu \mathrm{M}$ Trolox equivalent $/ \mathrm{mg}$ sample), corn $(32.9 \mu \mathrm{M}$ Trolox equivalent/g sample) and cottonseed (88.30 $\mu \mathrm{M}$ Trolox equivalent/mg sample) protein hydrolysates (Zhou et al. 2012; Ambigaipalan et al. 2015; Phongthai et al. 2018; Song et al. 2020). In the case of ABTS, the results in this study were also higher than those reported for jujube (Ziziphus jujube) seed protein $(9.14 \mu \mathrm{M}$ Trolox equivalent/mg sample), okra (Abelmoschus esculentus) protein hydrolysate $(132.2 \mu \mathrm{M}$ Trolox equivalent/g sample) marine green microalgae (Tetraselmis suecica) $(696.99 \mu \mathrm{M}$ Trolox equivalent/g sample) and chia seed (Salvia hispanica) $(506.07 \mu \mathrm{M}$ Trolox equivalent/mg sample) protein hydrolysates (Jiménez-Escrig et al. 2010; Kanbargi et al. 2016; Norzagaray-Valenzuela et al. 2017; Urbizo-Reyes et al. 2019). The high content of hydrophobic fractions in CSP could play a role in the antioxidant observed in this study. Hall et al. (2018) indicated that peptides with predominant hydrophobicity could increase their interaction with peroxyl radicals such as DPPH. Thus, other criteria (e.g., molecular weight, amino acid position in the sequence, amino acid composition) can contribute to CSP's antioxidant activity. In this context, Ketnawa et al. (2018a, 2018b) showed that specific amino acids (proline, leucine, alanine, and aromatic amino acids) and low molecular weight could play a role in the antioxidant activity and the stability of peptides through gastrointestinal digestion.

Furthermore, it has been shown that protein from canary seed contains a higher content of aromatic amino acids phenylalanine and tryptophan compared to other protein sources such as casein and wheat (Abdel-Aal et al. 1997). Finally, research on CSP's antioxidant stability through gastrointestinal digestion and their role in serving as antioxidant agents in food and in vivo models is required.

\section{Conclusion}

This study determined that using an oil extraction process prior to hydrolyzing canary seeds improved the overall separation of the canary seed components, particularly the protein yield. Additionally, this study represents the first insight into the inhibitory capacity of defatted canary seed peptides produced using a commercial, food-grade enzyme (Alcalase) towards ACE, DPPIV, lipase, and $\alpha$-glucosidase. These peptides' inhibitory 
capacity showed the potential of canary seeds to serve as a source of natural bioactive compounds for the formulation of functional foods aimed at some of the most common non-communicable diseases (e.g., hypertension, diabetes, and obesity). In this study, the low molecular weight canary seed peptide fractions $(<3 \mathrm{kDa}$ and $3-10$ $\mathrm{kDa}$ ) displayed similar biological activity to other plantderived bioactive peptides by inhibiting ACE, lipase, DPP-IV, and $\alpha$-glucosidase enzymes. The $\mathrm{ACE} \mathrm{IC}_{50}$ values were also 10 -fold lower than those previously reported for canary seeds, highlighting the effectiveness of using a commercial enzyme on defatted seeds. Finally, these peptides' high antioxidant activity against free radical's DPPH and ABTS demonstrate their potential use as active ingredients in functional foods or pharmaceutical products. However, further studies are necessary to characterize the peptides responsible for the observed bioactivities. Particularly, proteomics studies are required to determine sequences, structure-activity relationships, as well as in silico docking modeling studies to observe the enzyme-peptide interactions (e.g., ACE, lipase, DPP-IV, and $\alpha$-glucosidase enzymes). Further bioavailability and bioaccessibility studies must be pursued to confirm the transport capabilities and stability of these peptides, and in vivo studies are needed to validate their physiological effect.

\section{Supplementary Information}

The online version contains supplementary material available at https://doi. org/10.1186/s43014-020-00050-w.

Additional file 1 SDS-PAGE of canary seed storage protein fractions Lane numbers indicate: 1, Molecular weight markers; 2, Albumins; 3, Globulins 7s; 4, Globulin 11 s; 5, Prolamins; 6, Glutelins. Enzyme inhibition $\left(\mathrm{IC}_{50}\right)$ of canary seed peptide fractions.

\section{Acknowledgements}

Not applicable.

\section{Authors' contributions}

All authors contributed to the conception, design, and writing of this manuscript. Urbizo-Reyes and Aguilar-Toalá collected the data and prepared the initial draft. Liceaga supervised and managed the project. The authors read and approved the final manuscript.

\section{Funding}

This work is supported by the USDA National Institute of Food and Agriculture, Hatch Act formula funds project 1019794.

\section{Availability of data and materials \\ Not applicable.}

Ethics approval and consent to participate

Not applicable.

\section{Consent for publication}

Not applicable.

\section{Competing interests}

All authors declare no competing interests.
Received: 18 September 2020 Accepted: 27 December 2020

Published online: 03 February 2021

\section{References}

Abdel-Aal, E.-S. M., Hucl, P., Patterson, C. A., \& Gray, D. (2010). Fractionation of hairless canary seed (Phalaris canariensis) into starch, protein, and oil. Journal of Agricultural and Food Chemistry, 58(11), 7046-7050.

Abdel-Aal, E.-S. M., Hucl, P. J., \& Sosulski, F. W. (1997). Structural and compositional characteristic $\mathrm{S}$ of Canaryseed (Phalaris canariensis L.). Journal of Agricultural and Food Chemistry, 45(8), 3049-3055.

Adler-Nissen, J. (1986). Enzymic hydrolysis of food proteins. London: Elsevier.

Aguilar-Toalá, J. E., \& Liceaga, A. M. (2020). Identification of chia seed (Salvia hispanica L.) peptides with enzyme inhibition activity towards skin aging enzymes. Amino Acids. https://doi.org/10.1007/s00726-020-02879-4.

Alashi, A. M., Blanchard, C. L., Mailer, R. J., Agboola, S. O., Mawson, A. J., He, R., ... Aluko, R. E. (2014). Antioxidant properties of Australian canola meal protein hydrolysated. Food Chemistry, 146, 191-200.

Alcaide-Hidalgo, J. M., Romero, M., Duarte, J., \& López-Huertas, E. (2020). Antihypertensive effects of virgin olive oil (unfiltered) low molecular weight peptides with ACE inhibitory activity in spontaneously hypertensive rats. Nutrients, 12(1), 271.

Ambigaipalan, P., Al-Khalifa, A. S., \& Shahidi, F. (2015). Antioxidant and angiotensin I converting enzyme (ACE) inhibitory activities of date seed protein hydrolysates prepared using Alcalase, Flavourzyme and Thermolysin. Journal of Functional Foods, 18, 1125-1137.

AOAC (2016). Official methods of analysis of AOAC international, (20th ed., ). Rockville: AOAC International.

Arise, R. O., Idi, J. J., Mic-Braimoh, I. M., Korode, E., Ahmed, R. N., \& Osemwegie, O. (2019). In vitro Angiotesin-1-converting enzyme, a-amylase and a-glucosidase inhibitory and antioxidant activities of Luffa cylindrical (L.) M. Roem seed protein hydrolysate. Heliyon, 5(5), e01634.

Awosika, T. O., \& Aluko, R. E. (2019). Inhibition of the in vitro activities of aamylase, a-glucosidase and pancreatic lipase by yellow field pea (Pisum sativum L.) protein hydrolysates. International Journal of Food Science \& Technology, 54(6), 2021-2034.

Bai, M., Qin, G., Sun, Z., \& Long, G. (2016). Relationship between molecular structure characteristics of feed proteins and protein in vitro digestibility and solubility. Asian-Australasian Journal of Animal Sciences, 29(8), 1159.

Bakhle, Y. (2020). How ACE inhibitors transformed the renin-angiotensin system. British Journal of Pharmacology, 177(12), 2657-2665.

Balti, R., Bougatef, A., Ali, N. E. H., Zekri, D., Barkia, A., \& Nasri, M. (2010). Influence of degree of hydrolysis on functional properties and angiotensin I-converting enzyme-inhibitory activity of protein hydrolysates from cuttlefish (Sepia officinalis) by-products. Journal of the Science of Food and Agriculture, 90(12), 2006-2014.

Basile, A. J., Jasbi, P., Clark, W., Shi, X., Gu, H., Deviche, P., \& Sweazea, K. L. (2020). A four-week white bread diet does not alter plasma glucose concentrations, metabolic or vascular physiology in mourning doves, Zenaida macroura. In Comparative Biochemistry and Physiology Part A: Molecular \& Integrative Physiology, (p. 110718).

Birari, R. B., \& Bhutani, K. K. (2007). Pancreatic lipase inhibitors from natural sources: Unexplored potential. Drug Discovery Today, 12(19-20), 879-889.

Bower, A. M., Real Hernandez, L. M., Berhow, M. A., \& De Mejia, E. G. (2014). Bioactive compounds from culinary herbs inhibit a molecular target for type 2 diabetes management, dipeptidyl peptidase IV. Journal of Agricultural and Food Chemistry, 62(26), 6147-6158.

CDC's Healthy Communities Program - Preventing Chronic Diseases and Reducing Health Risk Factors. (2020). CDC.Gov. Retrieved fromhttps://www. cdc.gov/nccdphp/dch/programs/healthycommunitiesprogram/overview/ diseasesandrisks.htm.

Chatterjee, C., Gleddie, S., \& Xiao, C.-W. (2018). Soybean bioactive peptides and their functional properties. Nutrients, 10(9), 1211 Retrieved from https://www. mdpi.com/2072-6643/10/9/1211.

Chatterjee, S., Khunti, K., \& Davies, M. J. (2017). Type 2 diabetes. The Lancet, 389(10085), 2239-2251.

Chen, Z.-Y., Peng, C., Jiao, R., Wong, Y. M., Yang, N., \& Huang, Y. (2009). Antihypertensive nutraceuticals and functional foods. Journal of Agricultural and Food Chemistry, 57(11), 4485-4499.

Cheung, I. W., Nakayama, S., Hsu, M. N., Samaranayaka, A. G., \& Li-Chan, E. C. (2009). Angiotensin-I converting enzyme inhibitory activity of hydrolysates 
from oat (Avena sativa) proteins by in silico and in vitro analyses. Journal of Agricultural and Food Chemistry, 57(19), 9234-9242.

Chooi, Y. C., Ding, C., \& Magkos, F. (2019). The epidemiology of obesity. Metabolism, 92, 6-10

Cicero, A. F. G., Fogacci, F., \& Colletti, A. (2017). Potential role of bioactive peptides in prevention and treatment of chronic diseases: A narrative review. British Journal of Pharmacology, 174(11), 1378-1394. https://doi.org/10.1111/ bph.13608.

Coelho, M. S., Fernandes, S. S., \& Salas-Mellado, M. d. I. M. (2019). Chapter 9 association between diet, health, and the presence of bioactive compounds in foods. In M. R. S. Campos (Ed.), Bioactive compounds, (pp. 159-183). Cambridge: Woodhead Publishing.

Cogliatti, M. (2012). Canaryseed crop. Scientia Agropecuaria, 3(1), 75-88.

Drucker, D. J. (2007). Dipeptidyl peptidase-4 inhibition and the treatment of type 2 diabetes: Preclinical biology and mechanisms of action. Diabetes Care, 30(6), 1335-1343.

Estrada-Salas, P. A., Montero-Morán, G. M., Martínez-Cuevas, P. P., González, C., \& Barba de la Rosa, A. P. (2014). Characterization of antidiabetic and antihypertensive properties of canary seed (Phalaris canariensis L.) peptides. Journal of Agricultural and Food Chemistry, 62(2), 427-433.

Farvin, K. S., Andersen, L. L., Otte, J., Nielsen, H. H., Jessen, F., \& Jacobsen, C. (2016). Antioxidant activity of cod (Gadus morhua) protein hydrolysates: Fractionation and characterisation of peptide fractions. Food Chemistry, 204, 409-419.

Garzón, A. G., Cian, R. E., Aquino, M. E., \& Drago, S. R. (2020). Isolation and identification of cholesterol esterase and pancreatic lipase inhibitory peptides from brewer's spent grain by consecutive chromatography and mass spectrometry. Food \& Function, 11(6), 4994-5003.

González-Pérez, S., \& Arellano, J. B. (2009). Vegetable protein isolates. In Handbook of hydrocolloids, (pp. 383-419). Cambridge: Woodhead Publishing.

Gupta, M., Saxena, S., \& Goyal, D. (2015). Potential pancreatic lipase inhibitory activity of an endophytic Penicillium species. Journal of Enzyme Inhibition and Medicinal Chemistry, 30(1), 15-21.

Hall, F., Johnson, P. E., \& Liceaga, A. (2018). Effect of enzymatic hydrolysis on bioactive properties and allergenicity of cricket (Gryllodes sigillatus) protein. Food Chemistry, 262, 39-47. https://doi.org/10.1016/j.foodchem.2018.04.058.

Hatanaka, T., Inoue, Y., Arima, J., Kumagai, Y., Usuki, H., Kawakami, K., ... Mukaihara, T. (2012). Production of dipeptidyl peptidase IV inhibitory peptides from defatted rice bran. Food Chemistry, 134(2), 797-802.

Ishida, Y., Shibata, Y., Fukuhara, I., Yano, Y., Takehara, I., \& Kaneko, K. (2011). Effect of an excess intake of casein hydrolysate containing Val-pro-pro and Ile-propro in subjects with normal blood pressure, high-normal blood pressure, or mild hypertension. Bioscience, Biotechnology, and Biochemistry, 75(3), 427-433.

Jakubczyk, A., Szymanowska, U., Karaś, M., Złotek, U., \& Kowalczyk, D. (2019). Potential anti-inflammatory and lipase inhibitory peptides generated by in vitro gastrointestinal hydrolysis of heat treated millet grains. CyTA Journal of Food, 17(1), 324-333.

Jia, J., Ma, H., Zhao, W., Wang, Z., Tian, W., Luo, L., \& He, R. (2010). The use of ultrasound for enzymatic preparation of ACE-inhibitory peptides from wheat germ protein. Food Chemistry, 119(1), 336-342.

Jiménez-Escrig, A., Alaiz, M., Vioque, J., \& Rupérez, P. (2010). Health-promoting activities of ultra-filtered okara protein hydrolysates released by in vitro gastrointestinal digestion: Identification of active peptide from soybean lipoxygenase. European Food Research and Technology, 230(4), 655-663.

Kanbargi, K. D., Sonawane, S. K., \& Arya, S. S. (2016). Functional and antioxidant activity of Ziziphus jujube seed protein hydrolysates. Journal of Food Measurement and Characterization, 10(2), 226-235.

Ketnawa, S., \& Liceaga, A. M. (2017). Effect of microwave treatments on antioxidant activity and antigenicity of fish frame protein hydrolysates. Food and Bioprocess Technology, 10(3), 582-591.

Ketnawa, S., Suwal, S., Huang, J. Y., \& Liceaga, A. M. (2018a). Selective separation and characterisation of dual ACE and DPP-IV inhibitory peptides from rainbow trout (Oncorhynchus mykiss) protein hydrolysates. International Journal of Food Science \& Technology, 54(4), 1062-1073.

Ketnawa, S., Wickramathilaka, M., \& Liceaga, A. M. (2018b). Changes on antioxidant activity of microwave-treated protein hydrolysates after simulated gastrointestinal digestion: Purification and identification. Food Chemistry, 254, 36-46.

Konrad, B., Anna, D., Marek, S., Marta, P., Aleksandra, Z., \& Józefa, C. (2014). The evaluation of dipeptidyl peptidase (DPP)-IV, a-glucosidase and angiotensin converting enzyme (ACE) inhibitory activities of whey proteins hydrolyzed with serine protease isolated from asian pumpkin (Cucurbita ficifolia). International Journal of Peptide Research and Therapeutics, 20(4), 483-491. https://doi.org/10.1007/s10989-014-9413-0.

Krichen, F., Sila, A., Caron, J., Kobbi, S., Nedjar, N., Miled, N., ... Bougatef, A. (2018). Identification and molecular docking of novel ACE inhibitory peptides from protein hydrolysates of shrimp waste. Engineering in Life Sciences, 18(9), 682-691.

Kumar, R., Kumar, A., Sharma, R., \& Baruwa, A. (2010). Pharmacological review on natural ACE inhibitors. Der Pharmacia Lettre, 2(2), 273-293.

Kumar, S., Narwal, S., Kumar, V., \& Prakash, O. (2011). a-Glucosidase inhibitors from plants: A natural approach to treat diabetes. Pharmacognosy Reviews, 5(9), 19.

Liceaga-Gesualdo, A., \& Li-Chan, E. C. Y. (1999). Functional properties of fish protein hydrolysate from herring (Clupea harengus). Journal of Food Science, 64(6), 1000-1004.

Liu, L., Wang, Y., Peng, C., \& Wang, J. (2013). Optimization of the preparation of fish protein anti-obesity hydrolysates using response surface methodology. International Journal of Molecular Sciences, 14(2), 3124-3139.

Lobo, V., Patil, A., Phatak, A., \& Chandra, N. (2010). Free radicals, antioxidants and functional foods: Impact on human health. Pharmacognosy Reviews, 4(8), 118-126. https://doi.org/10.4103/0973-7847.70902.

Mäkinen, S., Johannson, T., Gerd, E. V., Pihlava, J. M., \& Pihlanto, A. (2012). Angiotensin I-converting enzyme inhibitory and antioxidant properties of rapeseed hydrolysates. Journal of Functional Foods, 4(3), 575-583.

Malekzad, H., Mirshekari, H., Sahandi Zangabad, P., Moosavi Basri, S., Baniasadi, F., Sharifi Aghdam, M., ... Hamblin, M. R. (2018). Plant protein-based hydrophobic fine and ultrafine carrier particles in drug delivery systems. Critical Reviews in Biotechnology, 38(1), 47-67.

Marambe, P., \& Wanasundara, J. (2012). Seed storage proteins as sources of bioactive peptides. In Bioactive molecules in plant foods, (pp. 49-80).

Mason, E. (2019). Nutritional and bioactive properties of glabrous canaryseed (Phalaris canariensis, L.) proteins (Doctoral dissertation, McGill University), Montreal, Quebec.

Mason, E., L'Hocine, L., Achouri, A., \& Karboune, S. (2018). Hairless Canaryseed: A novel cereal with health promoting potential. Nutrients, 10(9), 1327.

Mudgil, P., Kamal, H., Yuen, G. C., \& Maqsood, S. (2018). Characterization and identification of novel antidiabetic and anti-obesity peptides from camel milk protein hydrolysates. Food Chemistry, 259, 46-54.

Mune, M. A. M., Minka, S. R., \& Henle, T. (2018). Investigation on antioxidant, angiotensin converting enzyme and dipeptidyl peptidase IV inhibitory activity of Bambara bean protein hydrolysates. Food Chemistry, 250, 162-169.

Nadathur, S. R., Wanasundara, J. P. D., \& Scanlin, L. (2017). Chapter 1 - proteins in the diet: Challenges in feeding the global population. In S. R. Nadathur, J. P. D. Wanasundara, \& L. Scanlin (Eds.), Sustainable protein sources, (pp. 1-19). San Diego: Academic.

Nauck, M. A., \& Meier, J. J. (2016). The incretin effect in healthy individuals and those with type 2 diabetes: Physiology, pathophysiology, and response to therapeutic interventions. The lancet Diabetes \& Endocrinology, 4(6), 525-536.

Ngoh, Y. Y., \& Gan, C. Y. (2016). Enzyme-assisted extraction and identification of antioxidative and a-amylase inhibitory peptides from pinto beans (Phaseolus vulgaris Cv. Pinto). Food Chemistry, 190, 331-337.

Nongonierma, A. B., \& FitzGerald, R. J. (2015). Investigation of the potential of hemp, pea, rice and soy protein hydrolysates as a source of dipeptidyl peptidase IV (DPP-IV) inhibitory peptides. Food Digestion: Research and Current Opinion, 6(1-3), 19-29.

Nongonierma, A. B., Paolella, S., Mudgil, P., Maqsood, S., \& FitzGerald, R. J. (2018). Identification of novel dipeptidyl peptidase IV (DPP-IV) inhibitory peptides in camel milk protein hydrolysates. Food Chemistry, 244, 340-348.

Norzagaray-Valenzuela, C. D., Valdez-Ortiz, A., Shelton, L. M., Jiménez-Edeza, M., Rivera-López, J., Valdez-Flores, M. A., \& Germán-Báez, L. J. (2017). Residual biomasses and protein hydrolysates of three green microalgae species exhibit antioxidant and anti-aging activity. Journal of Applied Phycology, 29(1), 189-198.

Perez Gutierrez, R. M., Ahuatzi, D. M., Cruz Victoria, T., \& Madrigales Ahuatzi, D. (2016). Inhibition by seeds of Phalaris canariensis extracts of key enzymes linked to obesity. Alternative Therapies in Health \& Medicine, 22(1), 8-14.

Phongthai, S., D'Amico, S., Schoenlechner, R., Homthawornchoo, W., \& Rawdkuen, S. (2018). Fractionation and antioxidant properties of rice bran protein hydrolysates stimulated by in vitro gastrointestinal digestion. Food Chemistry, 240, 156-164. 
Pihlanto-Leppälä, A. (2000). Bioactive peptides derived from bovine whey proteins: Opioid and ace-inhibitory peptides. Trends in Food Science \& Technology, 11(9-10), 347-356.

Poovitha, S., \& Parani, M. (2016). In vitro and in vivo a-amylase and a-glucosidase inhibiting activities of the protein extracts from two varieties of bitter gourd (Momordica charantia L.). BMC Complementary and Alternative Medicine, 16(1), $1-8$.

Rajamohamed, S. H., Aryee, A. N., Hucl, P., Patterson, C. A., \& Boye, J. I. (2013). In vitro gastrointestinal digestion of glabrous canaryseed proteins as affected by variety and thermal treatment. Plant Foods for Human Nutrition, 68(3), 306312.

Ren, Y., Liang, K., Jin, Y., Zhang, M., Chen, Y., Wu, H., \& Lai, F. (2016). Identification and characterization of two novel a-glucosidase inhibitory oligopeptides from hemp (Cannabis sativa L.) seed protein. Journal of Functional Foods, 26, 439-450.

Roskar, I., Molek, P., Vodnik, M., Stempelj, M., Strukelj, B., \& Lunder, M. (2015). Peptide modulators of alpha-glucosidase. Journal of Diabetes Investigation, 6(6), 625-631

Sá, A. G. A., Moreno, Y. M. F., \& Carciofi, B. A. M. (2020). Plant proteins as highquality nutritional source for human diet. Trends in Food Science \& Technology, 97, 170-184. https://doi.org/10.1016/j.tifs.2020.01.011.

Sánchez, A., \& Vázquez, A. (2017). Bioactive peptides: A review. Food Quality and Safety, 1(1), 29-46.

Sarmadi, B. H., \& Ismail, A. J. P. (2010). Antioxidative peptides from food proteins: A review, Peptides, 31(10), 1949-1956.

Schalk, K., Lexhaller, B., Koehler, P., \& Scherf, K. A. (2017). Isolation and characterization of gluten protein types from wheat, rye, barley and oats for use as reference materials. PLoS One, 12(2), e0172819.

Shewry, P. R., \& Halford, N. G. (2002). Cereal seed storage proteins: Structures, properties and role in grain utilization. Journal of Experimental Botany, 53(370), 947-958

Song, W., Kong, X., Hua, Y., Li, X., Zhang, C., \& Chen, Y. (2020). Antioxidant and antibacterial activity and in vitro digestion stability of cottonseed protein hydrolysates. LWT, 118, 108724

Sultana, R., Alashi, A. M., Islam, K., Saifullah, M., Haque, C. E., \& Aluko, R. E. (2020) Inhibitory activities of Polyphenolic extracts of Bangladeshi vegetables against a-amylase, a-glucosidase, pancreatic lipase, renin, and angiotensinconverting enzyme. Foods, 9(7), 844.

Tschiersch, C., Nikfardjam, M. P., Schmidt, O., \& Schwack, W. (2010). Degree of hydrolysis of some vegetable proteins used as fining agents and its influence on polyphenol removal from red wine. European Food Research and Technology, 231(1), 65-74.

Urbizo-Reyes, U., San Martin-González, M. F., Garcia-Bravo, J., López Malo, A., \& Liceaga, A. M. (2019). Physicochemical characteristics of chia seed (Salvia hispanica) protein hydrolysates produced using ultrasonication followed by microwave-assisted hydrolysis. Food Hydrocolloids, 105187. https://doi.org/10. 1016/j.foodhyd.2019.105187.

Valverde, M. E., Orona-Tamayo, D., Nieto-Rendón, B., \& Paredes-López, O. (2017) Antioxidant and antihypertensive potential of protein fractions from flour and milk substitutes from canary seeds (Phalaris canariensis L.). Plant Foods for Human Nutrition, 72(1), 20-25.

Varghese, G. K., Bose, L. V., \& Habtemariam, S. (2013). Antidiabetic components of Cassia alata leaves: Identification through a-glucosidase inhibition studies. Pharmaceutical Biology, 51(3), 345-349.

Velarde-Salcedo, A. J., Barrera-Pacheco, A. Lara-González, S, Montero-Morán, G. M., Díaz-Gois, A., de Mejia, E. G., \& de la Rosa, A. P. B. J. F. c. (2013). In vitro inhibition of dipeptidyl peptidase IV by peptides derived from the hydrolysis of amaranth (Amaranthus hypochondriacus L.) proteins, 136(2), 758-764.

Vilcacundo, R., Martínez-Villaluenga, C., \& Hernández-Ledesma, B. (2017). Release of dipeptidyl peptidase IV, a-amylase and a-glucosidase inhibitory peptides from quinoa (Chenopodium quinoa Willd.) during in vitro simulated gastrointestinal digestion. Journal of Functional Foods, $35,531-539$

Wang, R., Zhao, H., Pan, X., Orfila, C., Lu, W., \& Ma, Y. (2019). Preparation of bioactive peptides with antidiabetic, antihypertensive, and antioxidant activities and identification of a-glucosidase inhibitory peptides from soy protein. Food Science \& Nutrition, 7(5), 1848-1856.

Zhang, M., Mu, T. H., \& Sun, M. J. (2014). Purification and identification of antioxidant peptides from sweet potato protein hydrolysated by alcalase. Journal of Functional Foods, 7, 191-200.
Zhang, S., Zheng, L., Zheng, X., Ai, B., Yang, Y., Pan, Y., \& Sheng, Z. (2019). Effect of steam explosion treatments on the functional properties and structure of camellia (Camellia oleifera Abel.) seed cake protein. Food Hydrocolloids, 93, 189-197.

Zhou, K., Sun, S., \& Canning, C. (2012). Production and functional characterisation of antioxidative hydrolysates from corn protein via enzymatic hydrolysis and ultrafiltration. Food Chemistry, 135(3), 1192-1197.

Zou, T. B., He, T. P., Li, H. B., Tang, H. W., \& Xia, E. Q. (2016). The structureactivity relationship of the antioxidant peptides from natural proteins. Molecules, 21, 72.

\section{Publisher's Note}

Springer Nature remains neutral with regard to jurisdictional claims in published maps and institutional affiliations.
Ready to submit your research? Choose BMC and benefit from:

- fast, convenient online submission

- thorough peer review by experienced researchers in your field

- rapid publication on acceptance

- support for research data, including large and complex data types

- gold Open Access which fosters wider collaboration and increased citations

- maximum visibility for your research: over $100 \mathrm{M}$ website views per year

At $\mathrm{BMC}$, research is always in progress.

Learn more biomedcentral.com/submissions 